Article

\title{
Zoning and Analysis of Control Units for Water Pollution Control in the Yangtze River Basin, China
}

\author{
Fuliang Deng ${ }^{1,2}$, Tao Lin ${ }^{2, *}$ (D), Yue Zhao ${ }^{3}$ and Ying Yuan ${ }^{1}$ \\ 1 Institute of Space Information Technology, Xiamen University of Technology, Xiamen 361024, China; \\ fldeng8266@xmut.edu.cn (F.D.); yuanying@xmut.edu.cn (Y.Y.) \\ 2 Institute of Urban Environment, Chinese Academy of Sciences, Xiamen 361021, China \\ 3 Environmental Planning Institute, Ministry of Environmental Protection, Beijing 100012, China; \\ zhaoyue@caep.org.cn \\ * Correspondence: tlin@iue.ac.cn; Tel.: +86-592-619-0651
}

Received: 21 June 2017; Accepted: 1 August 2017; Published: 4 August 2017

\begin{abstract}
In order to meet the needs of the control-unit-based water pollution prevention problem in China, we proposed a comprehensive control unit zoning method with the combined basic administrative region and objective watershed management. The method can effectively connect the natural characteristics of watershed water sources, three-level zoning of water resources, and comprehensively consider the pollution distribution, socio-economics and many other factors. The zoning process includes four steps: (1) Generate the multi-level hydrological unit; (2) Identify the multi-element water catchment units; (3) Obtain the control unit with the administrative boundary as the boundary; (4) Check and adjust the results to meet the actual needs. Based on this method, the Yangtze River Basin was divided into 568 control units with a total area of 1.91 million $\mathrm{km}^{2}$. These control units were used as the basic unit to analyze the water quality status and the results show that the upper reaches have good water quality, while the lower reaches have poor water quality and more serious water pollution. Our study helps the Ministry of Environmental Protection of China develop the list of control units that are needed to improve water quality during the "13th Five-Year Plan", with a goal to provide technical support for control-unit-based water pollution prevention and control in the future.
\end{abstract}

Keywords: water pollution prevention; control unit; catchment unit; Yangtze River Basin

\section{Introduction}

Watershed management is a key issue for regional water resource retention, ecosystem conservation and pollution reduction [1-4]. In the watershed management domain, the control unit is defined as a spatial management unit integrating administrative area, water body and control section. The control section is a water quality monitoring section on the downstream of the water body to control and reflect the pollution of upstream water body, and the control unit is the main pollutant control area to ensure water quality standards of the control area [5-8]. The main purpose of management units zoning is to decompose the complex water environment problems into various governance units $[2,5]$, so that the specific measures and policies can be implemented effectively to achieve environmental water quality improvement [9]. Hydrological units usually represent surface and sub-surface runoff aggregated above a certain measurement point, where the runoff conditions determine basin characteristics and are therefore suitable as the subjects of watershed water pollution control researches (Examples include: point-source and non-point source pollution) [5]. Many researchers also prefer the hydrological unit as the basis for control unit zoning. The United States Watershed Water Pollution Control (total maximum daily load (TMDL) Program divides control unit based on the Hydrological Response Unit Watershed and Subdivision Water Division Control Unit 
divided by the United States Geological Survey (USGS) [10-15]. Hydrological unit is an appropriate and viable practice to eliminate or minimize the risk at the watershed scale, as it presents water quality characterization. This allows a good insight into seasonal variation [16]. The governance unit here is also commonly referred to as a control unit. The control-unit-based regional water pollution zoning management is the concise experience of the river basin management at home and abroad [17]. The United States has established an integral, entire total maximum daily load (TMDL) management in which the key means to ensure surface water archives water quality standards $[6,18]$. However, governance units typically do not fit the environmentally relevant scales, resulting in inefficiencies, spatial externalities and spillovers [19]. Some processes consider both hydrological and political factors into the units zoning of watershed management. For example, the European Union's Water Framework Directive has strengthened the need for inclusive and deliberative modes of governance suited to horizontal interplay between hydrological and political-administrative scales of operation [20]. According to the experience and basic national conditions of water environment management of river basins in China, the watershed control unit is divided by taking both administrative area and watershed management into consideration. Also, the basin water environment management is reached by dealing well with the relations of the water environment within each unit and among units $[7,8,21]$.

The control-unit-based basin watershed environment management is the development trend of international protection of water environment in watershed [22-24]. However, due to the influence of many factors such as national policy, spatial scale and management style, understandings of control unit connotation, zoning purpose, index system and their resultant verification are different, there is no uniform method of control unit zoning in the world [25,26]. In view of this, to establish a scientific control-unit-based water environment management system in China during the "13th Five-Year Plan" period and to implement fine and differential water environment management at all administrative levels, in this paper, a comprehensive zoning method of watershed control units for water pollution prevention is proposed. A case study was established to divide the control unit of the Yangtze River Basin and analyze the status of water pollution in the Yangtze River Basin.

\section{Materials and Methods}

\subsection{Study Area}

The Yangtze River Basin is China's largest basin. Its main stream is $6397 \mathrm{~km}$ long and covers $1.8 \times 10^{6} \mathrm{~km}^{2}$ of the total basin area, accounting for $18.8 \%$ of China's land area and raising a third of China's population. However, with the rapid development of the economy and urbanization, the problem of water pollution in the Yangtze River is becoming more and more serious, which brings harm to human health and social development. In April 2015, the China State Council issued the "Water Pollution Prevention Action Plan" and clearly put forward a plan to implement sub-basin, sub-region, phased scientific governance in China's key river basins. Therefore, how to effectively divide water pollution control unit in the Yangtze River Basin and further develop refined, differentiated water pollution prevention and control strategies based on water pollution status of each unit is a great challenge for the current management of water environment in the Yangtze River basin.

\subsection{Control Unit Zoning}

\subsubsection{Zoning Regulations}

In order to fully reflect the effective convergence of watershed management with natural water resources catchment norm, water pollution catchment characteristics and administrative areas management, this control unit division is divided by following four regulations according to the basin full coverage principle, administrative integrity, water integrity, water-based land-dividing principles $[5-8,16]$. 
a. The division of hydrological units should be connected with the three-level division of water resources. The Ministry of Water Resources divided the national water resources into three sub-regions including 10 of the first-level districts, 80 of the second-level regions and 210 of the third-level areas. Based on the natural characteristics and water flow characteristics of the catchment, the third-level water resources area was further divided into three levels of hydrological units, so that the next control unit can be refined to the township as the smallest administrative unit.

b. The control cross-section was considered as a node and the distribution of pollution sources within the region and sewage destination were considered as the dominant direction. The control unit is a spatial management unit delineated in three aspects: the water body, the catchment area and the control section. The water quality in the area should be given priority. Water quality in the control section mainly depends on the distribution of pollution sources within the control unit and the sewage destination.

c. Control unit should be demarcated using the provincial boundaries with the township as the smallest administrative unit, which will ensure the implementation and enforcement of the relevant policies and to achieve the coordination of river basin management and administrative management. That is, the control unit is not inter-provincial with a township only being zoned into one control unit, but composed of multi-township zoning boundaries with similar/close catchment features.

d. The control unit zoning should follow the principles of the trend-improving model [22] and is a long-term, continuous, coordinated, feedback and perfecting process. In this process, the location, section type, pollution sources type and distribution, land use and other factors may change, and the impact of these changes is very complex. One-time zoning cannot be completely enough, but only continues to improve and perfect based on the actual situation toward the established objectives of watershed water environment management.

\subsubsection{Zoning Process}

From the view of executive procedures, the control unit zoning is a process of allocation from top to bottom, and level-by-level docking from bottom to top. Figure 1 shows the flowchart of the control unit zoning process, which consists of four steps: (1) Generate the multi-level hydrological unit using hydrolytic analysis techniques based on the digital elevation model, three-level water resources zoning data and hydrological data. (2) Identify the multi-element water catchment units on the basis of the generated hydrological units and merge the hydrological units with similar water pollution characteristics by superimposing the control sections, water maps, sewage data, socio-economic data, land use data, etc. (3) Generate the control unit and analyze the identified catchment units together with the township-level administrative data and administrative resident data to obtain the control unit with the administrative boundary as the boundary. (4) Check and adjust the results by investigating and analyzing water pollution of each control unit onsite in the river basin with expert evaluation, followed by re-zoning, re-checking and re-adjusting those units unable to meet the actual needs until obtaining the "best" control units. The details of the zoning method and process will be explained with the following case study. 


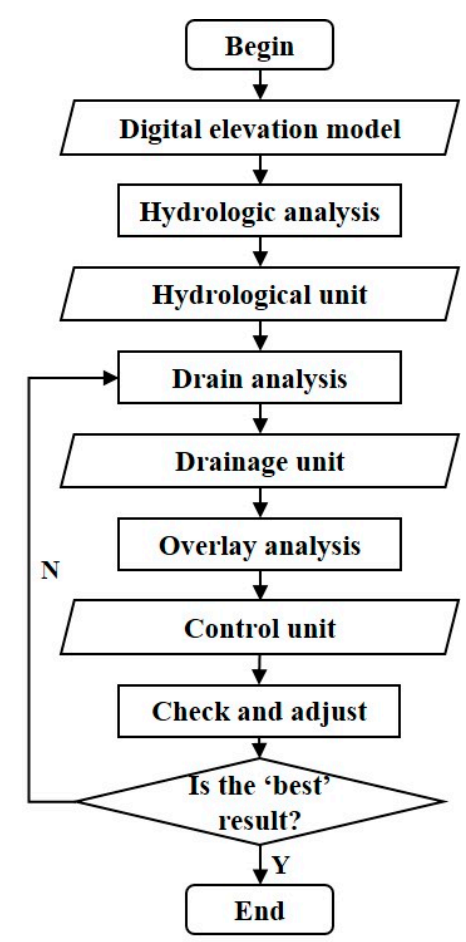

Figure 1. Process of dividing control unit for watershed management.

\section{Results}

\subsection{Control Unit Zoning in the Yangtze River Basin}

\subsubsection{Generation of Hydrological Units}

In order to effectively connect the existing water resources zones and realize the finer shape of the control catchment area, we draw lessons from the experience of an American five-level water zoning at macro scale $[27,28]$. Also based on the three-level water resources zones of the Ministry of Water Resources, we further refine the three-level water resources zones in the Yangtze River Basin. In other words, the watershed in the Yangtze River Basin is divided into six-level water resources zones. Figure 2 shows the three-level water resources zones in the Yangtze River Basin, including 12 second-level water resources zones and 45 third-level water resources zones.

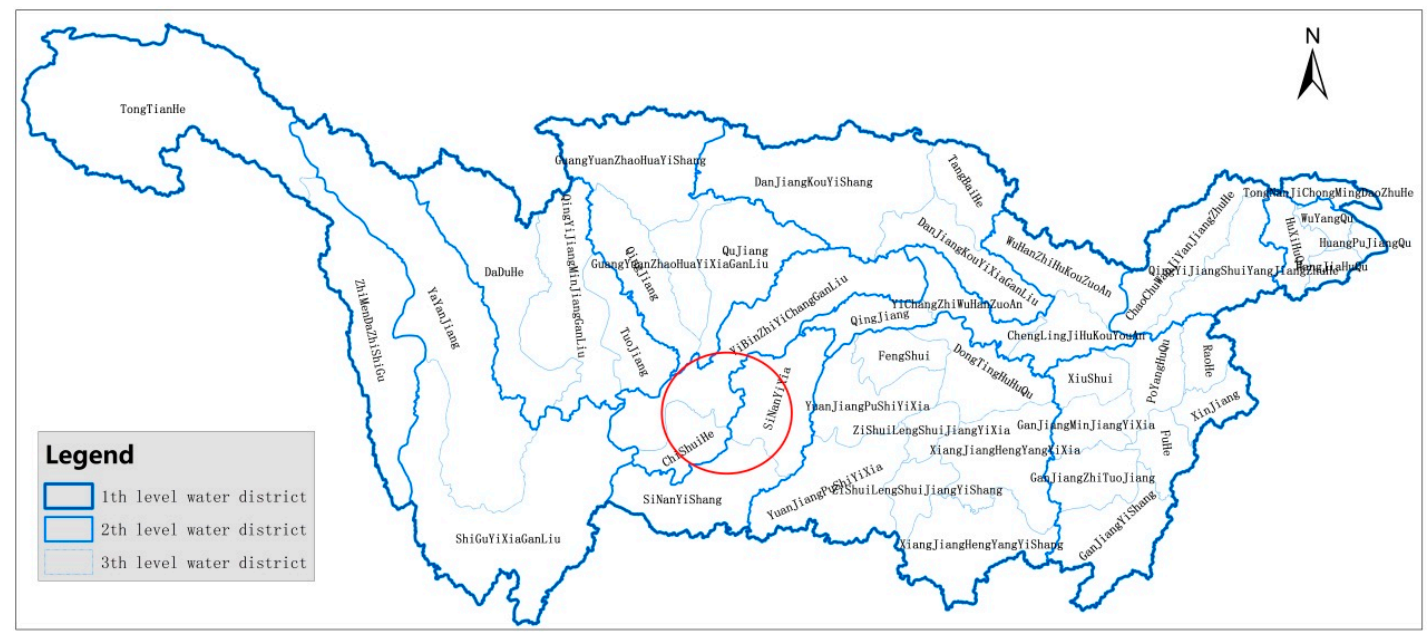

Figure 2. Three-level water district of the Yangtze River Basin. 
Figure 3-I shows the Chishui River Zone, a third-level water zone in the Yangtze River Basin. The zone is further divided into the fourth-level hydrological units (Figure 3-II), the fifth-level small hydrological units (Figure 3-III), and the sixth-level micro hydrology units (Figure 3-IV) based on the data of 30-meter resolution digital elevation model (DEM) using GIS hydrological analysis tools [29-31] with the boundary being the boundaries of the Chishui River Zone. Together with the three-level water resources zoning, the newly created three-level hydrological units form a multi-level hydrological zone for the whole basin, as shown in Figure 3-V. This multi-level hydrological unit can define the geographical range of watersheds at different scales, and contains the inclusion relation between the upper and lower reaches of the river basins at different levels, the adjacency or juxtaposition among the same level watershed, and the relations of tributaries with the river (lake, reservoir, sea, basin, etc.). Thus, it is an important basis for defining the geographical scope of catchment units.

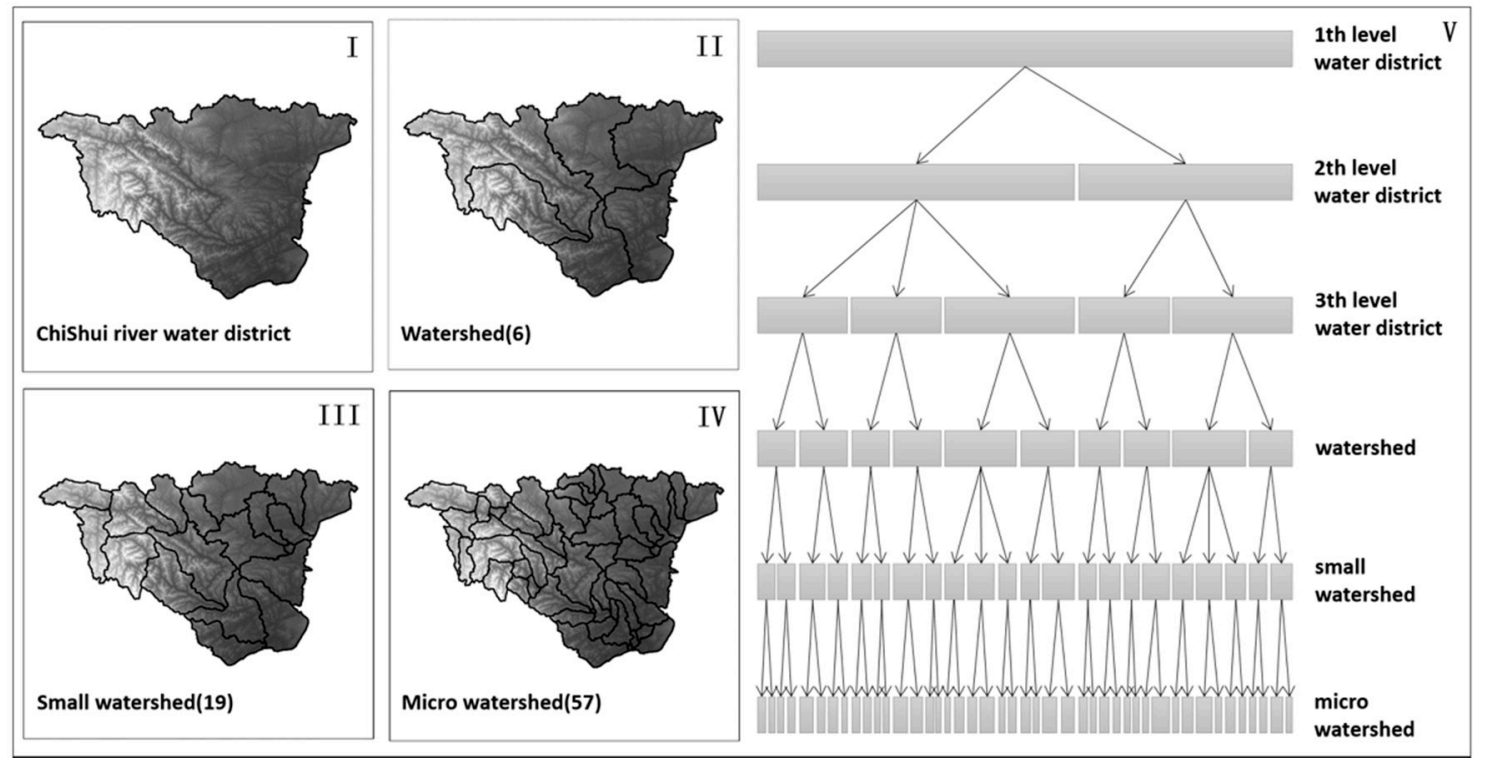

Figure 3. Schematic of hydrological unit division and multi-level representation.

\subsubsection{Identifying Catchment Units}

The main idea of identifying the catchment unit is to combine a number of similar/close hydrological units meeting the water pollution control targets into one space unit, i.e., catchment units, by catchment analysis using the control cross-section as a node, and according to the basin hydrological characteristics, flow direction, pollution source distribution, land use and other elements. In principle, each catchment unit corresponds to one main control section, and can contain multiple secondary control sections. The catchment unit changes with the main control section.

The identification of the catchment unit consists of the following three steps. First, select the control section. The control section is the water quality monitoring section setting at the downstream to control and reflect upstream water pollution. The selection and setting of control sections require comprehensively, and objectively, reflecting water quality as well as the spatiotemporal distribution and characteristics of pollutants in the water system or region. They should be set up in the water body with uniform water quality. Figure 4 shows the Zhuyang River control unit of Chongqing Section at the Yangtze River Basin. Second, form catchment units. The hydrological units of selected control sections are then merged using the selected control sections as nodes and labeled based on (1) the upper and lower basin containment relations and (2) flow direction relationship expressed by the multi-level hydrological units in combination with pollution source distribution, land use, etc. Then the labeled hydrological units are merged to form the preliminary catchment unit. Third, check and adjust the catchment units. This step is performed based on the basic principles of 
the control unit zoning, and mainly connects with the river basin management department, water environment management department and administrative department in addition to taking experts' recommendations. The preliminarily formed catchment unit should be adjusted and perfected under the premise of giving priority to the integrity of the water system in the catchment area to establish a catchment unit capable of reflecting the input response relationship between the pollution discharge and the water quality at the present stage. Figure 4 shows the identified catchment unit of the Zhuyan River control section.

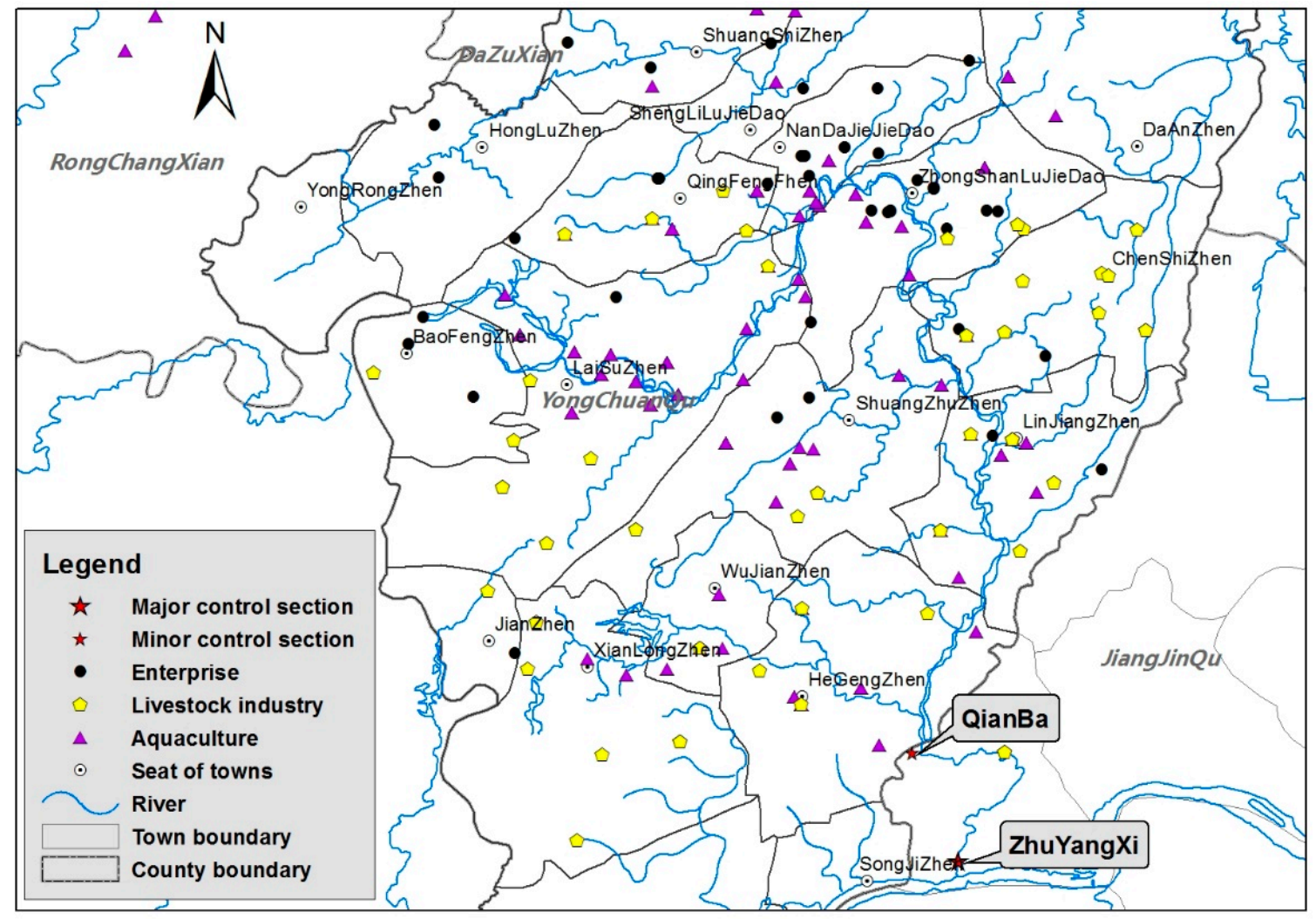

Figure 4. Schematic of drainage unit recognition.

\subsubsection{Control Unit Zoning}

In order to effectively clarify the main body of the responsibility of water environment management and to facilitate the implementation of the objectives and task allocation, the control unit zoning needs to combine administration and watershed management. Watershed management is reflected in the process of catchment unit identification. Watershed management can fully reflect the characteristics of natural convergence, water pollution, and land use characteristics, whereas administrative management is mainly reflected by the control unit boundary as the administrative boundary. In order to realize the meticulous management of water ecological environment in the river basin, we take the township as the smallest administrative unit, that is, the township as the control unit.

The main idea is to first mark the location of villages and townships that fall into the catchment unit using spatial superposition analysis construction based on the administrative districts and catchment-unit-based control unit zoning, and then merge all townships in the same catchment unit to obtain the control unit. As shown in Figure 5, the left side is the Zhuyang River catchment unit, and the right side is the Zhuyang River control unit generated by overlay analysis of the catchment unit and the township area. It can be seen that the spatial scope of the control unit is the merged boundary structure of the township zoning. 

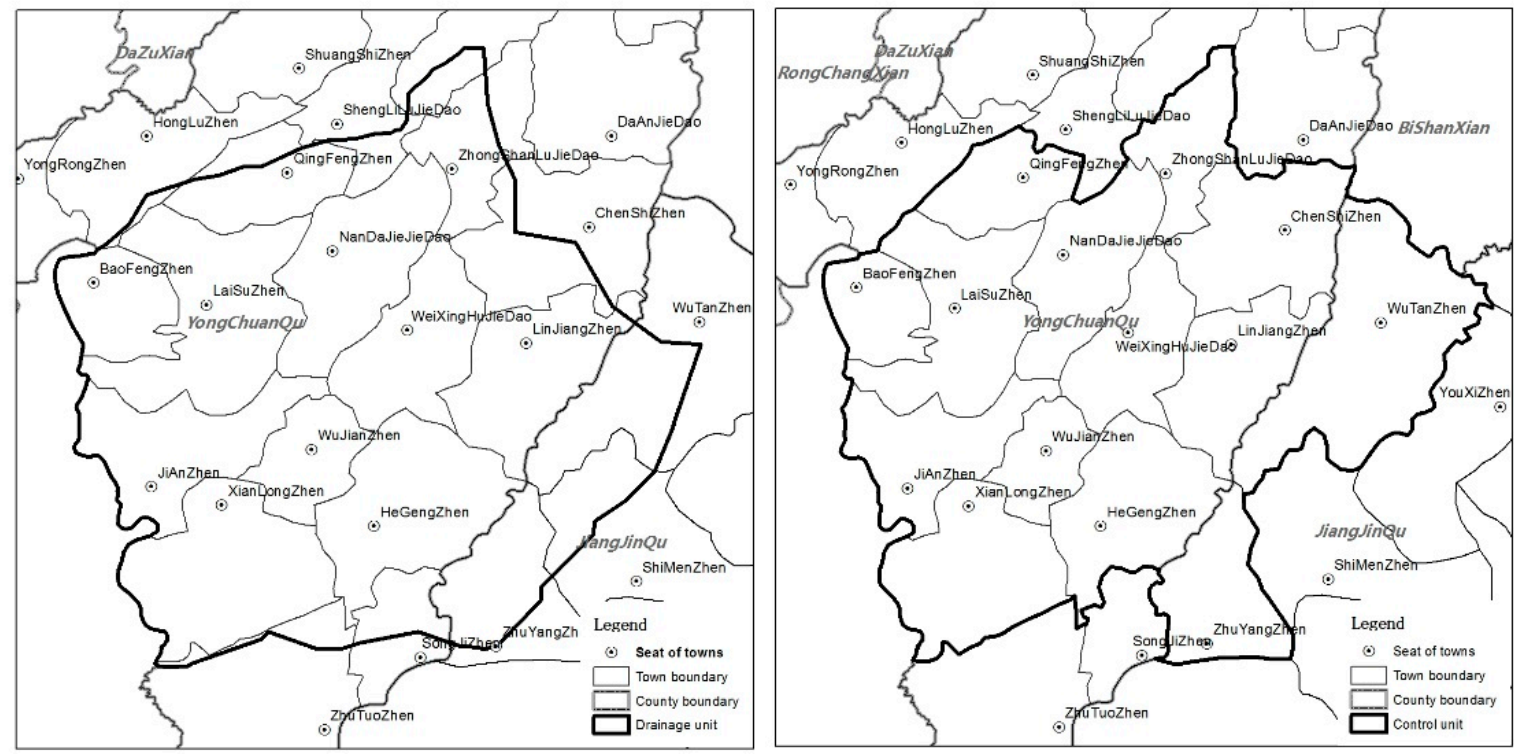

Figure 5. Schematic of control unit division based on district and drainage unit.

Table 1 is the statistical information of the "Linjiang River Jiangjin Control Unit 1", which is named as "water body name" + "city/county name" + "serial number" + "control unit". The unit number coding standard is "city/county code" + "water code"; the included townships are also listed as administrative units by districts and counties, so as to obtain the administrative districts involved in each control unit. Table 1 also includes the control unit assessment provinces, water quality and other information.

Table 1. Sample of the statistical items of control unit.

\begin{tabular}{cc}
\hline Items & Contents \\
\hline Control Unit & Linjiang River Jiangjin District Control Unit 1 \\
Unit number & 500118 F060 \\
Assessment provinces & Chongqin \\
Water body location & Linjiang River \\
Water body number & F060200 \\
Assessment Section & Zhuyang River \\
Water quality status quo in the "12th Five-Year Plan" period & IV \\
Water quality target in the "13th Five-Year Plan" period & III \\
District (Township) & Jinjiang District 500116 Zhuyang Township \\
\hline
\end{tabular}

\subsubsection{Evaluation and Adjustment}

The results of the control unit zoning need to be further evaluated and adjusted. If it meets the water environment management objectives of the watershed, it will be considered the final zoning result, otherwise, it needs to be further discussed with local experts. The main basis for the adjustment is the sewage and catchment situation of the township. However, other comprehensive factors including distribution of pollution sources, main city location, land use, and customs of ethnic groups should all be considered to determine the situation of catchment and be reflected in the process of catchment unit construction, making the final control unit zoning more reasonable.

\subsubsection{Zoning Results}

According to the control unit zoning method in this paper, the Yangtze River Basin is divided into a total of 568 control units. Among them, 1 is in Qinghai, 80 in Sichuan, 26 in Yunnan, 3 in Gansu, 34 in Guizhou, 15 in Shaanxi, 42 in Chongqing, 9 in Henan, 50 in Anhui, 72 in Jiangxi, 57 in Hunan, 
100 in Hubei, 42 in Jiangsu, 20 in Zhejiang, and 17 in Shanghai. These control units involve 623 control sections, of which 568 are main control sections and 55 are minor control sections. Figure 6 shows the zoning results. In the following sections, the situation of water pollution in the Yangtze River Basin during the "12th Five-Year Plan" period will be analyzed using these control units as the basic units.

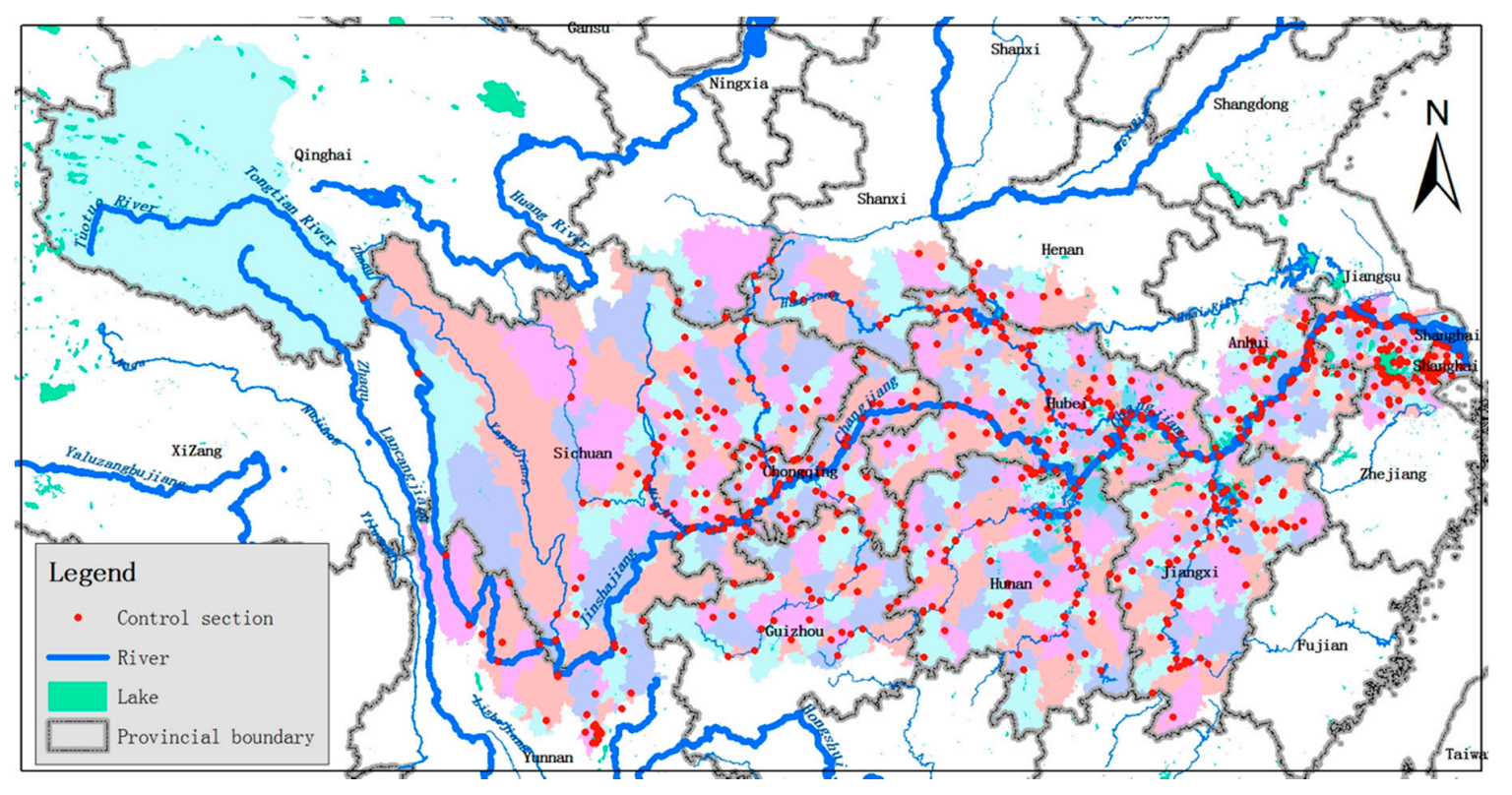

Figure 6. The map of control unit division for the Yangtze River Basin.

\subsection{Control-Unit-Based Analysis of Water Pollution in the Yangtze River Basin}

\subsubsection{Analysis of the Status of Water Quality}

Figure 7 shows the water quality of the Yangtze River Basin monitored by the National Control Section monitoring points during the "12th Five-Year Plan (2010-2015)". From the spatial distribution statistics, water pollution is very severe in the near bank of the mainstream of the Yangtze River Basin. Especially, the middle and lower reaches of the Yangtze River Basin such as Guizhou, Hubei, Jiangsu and Shanghai have become the most severe areas of water pollution. Among the main tributaries, water pollution is more severe in the downstream of Minjiang River, Wujiang River, Xiangjiang River and Hanjiang River. The total area of the 568 control units in the Yangtze River Basin is 1.91 million $\mathrm{km}^{2}$, of which $1,673,600 \mathrm{~km}^{2}$ of the control units meet or surpass the Grade III water quality standard, accounting for $87.59 \%$ of the total watershed area; 23.7 million $\mathrm{km}^{2}$ do not meet the Grade III water quality standard, accounting for $12.41 \% ; 149,100 \mathrm{~km}^{2}$ meet the Grade IV water quality standard, accounting for $7.8 \% ; 435,000 \mathrm{~km}^{2}$ meet the Grade V water quality standard, accounting for $2.28 \%$; $444,900 \mathrm{~km}^{2}$ do not meet the Grade V water quality standard, accounting for $2.33 \%$. The water quality of Dongting Lake, Poyang Lake, Taihu Lake and their surrounding lower reaches is worse than the Grade IV. In general, the overall water environment of the Yangtze River Basin is still in good condition. The upper reaches have good water quality, while the lower reaches have poor water quality and more serious water pollution, which has become a serious problem of the Yangtze River water environment. 


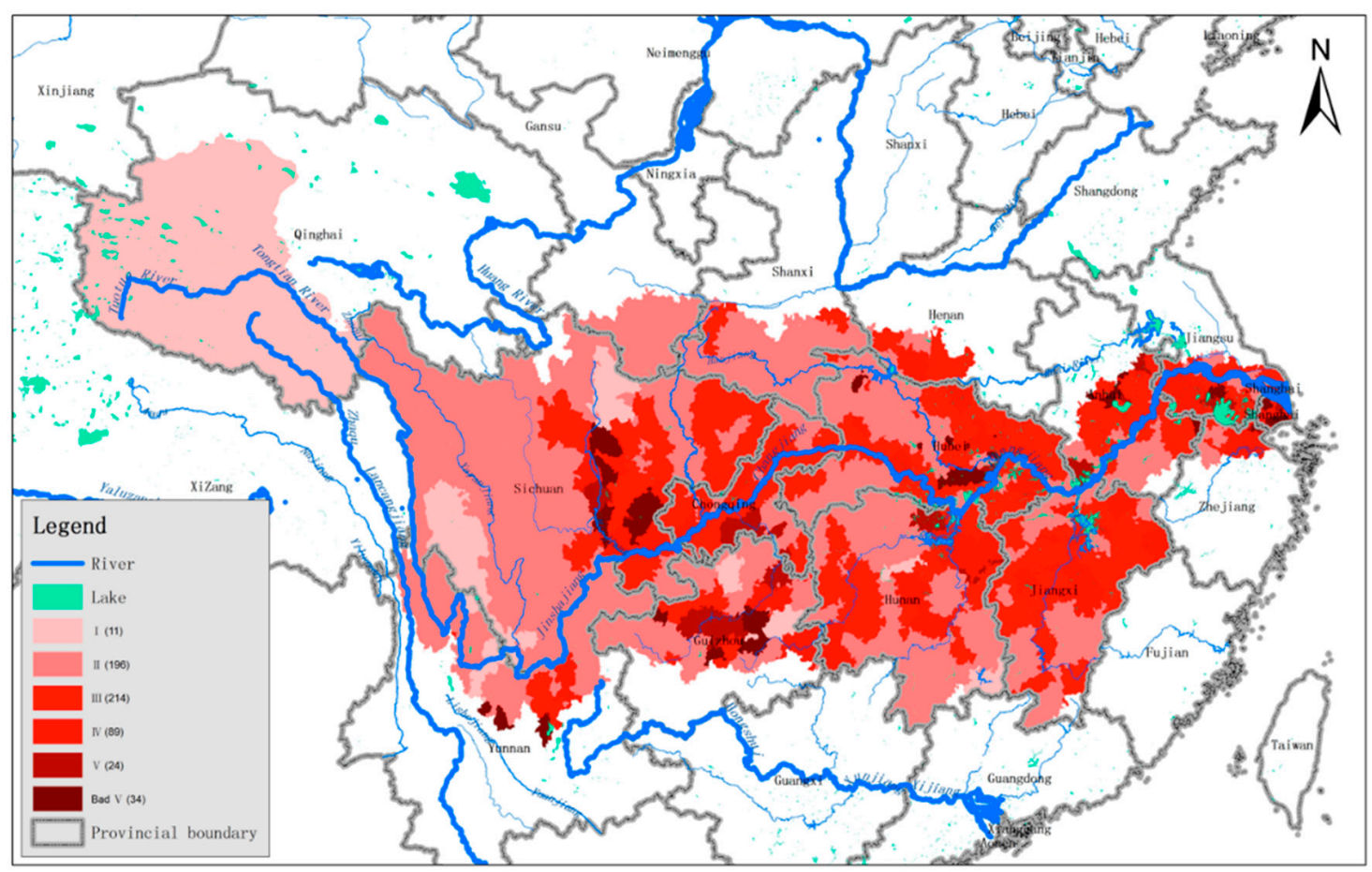

Figure 7. Distribution of water quality status quo in the Yangtze River Basin during the "12th Five-Year Plan".

As shown in Table 2, the statistics of the control units show that in the Yangtze River Basin during the "12th Five-Year Plan" period, 421 control units have water quality meeting or surpassing the Grade III standard, accounting for $74.1 \%$, and 147 control units have water quality below the Grade III standard, accounting for $25.9 \%$. Among them, water quality is Grade IV in 89 control units, accounting for $15.7 \%$, Grade V in 24 control units, accounting for $4.2 \%$, and below Grade V in 34 control units, accounting for $6.0 \%$. From the administrative district point view in the Yangtze River Basin, water pollution is serious in Shanghai, Zhejiang and Jiangsu, accounting for $58.8 \%, 45.0 \%$ and $42.9 \%$, respectively, of the total control units. They have water quality below the Grade III standard. The top three districts with most water quality below the Grade V standard are Shanghai, Guizhou and Yunnan, accounting for $23.5 \%, 14.7 \%$ and $11.5 \%$ of the total control units, respectively. These districts have more control units that need to improve water quality and have greater pressures to control environmental pollution. 
Table 2. Status quo of water quality in the Yangtze River basin during the "12th Five-Year" period.

\begin{tabular}{|c|c|c|c|c|c|c|c|c|c|c|c|c|c|}
\hline \multirow{3}{*}{$\begin{array}{l}\text { Administrative } \\
\text { Districts }\end{array}$} & \multirow{3}{*}{$\begin{array}{c}\text { No. of } \\
\text { Control } \\
\text { Unit }\end{array}$} & \multicolumn{12}{|c|}{ Water Quality During the "12th Five-Year" Period } \\
\hline & & \multicolumn{2}{|l|}{$\mathbf{I}$} & \multicolumn{2}{|l|}{ II } & \multicolumn{2}{|l|}{ III } & \multicolumn{2}{|l|}{ IV } & \multicolumn{2}{|l|}{ V } & \multicolumn{2}{|l|}{ Bad V } \\
\hline & & $\begin{array}{c}\text { No. of } \\
\text { Control Unit }\end{array}$ & $\begin{array}{c}\text { of } \\
\text { Total\% }\end{array}$ & $\begin{array}{l}\text { No. of } \\
\text { Control Unit }\end{array}$ & $\begin{array}{c}\text { of } \\
\text { Total\% }\end{array}$ & $\begin{array}{c}\text { No. of } \\
\text { Control Unit }\end{array}$ & $\begin{array}{c}\text { of } \\
\text { Total } \%\end{array}$ & $\begin{array}{c}\text { No. of } \\
\text { Control Unit }\end{array}$ & $\begin{array}{c}\text { of } \\
\text { Total } \% \\
\end{array}$ & $\begin{array}{c}\text { No. of } \\
\text { Control Unit }\end{array}$ & $\begin{array}{c}\text { of } \\
\text { Total } \%\end{array}$ & $\begin{array}{l}\text { No. of } \\
\text { Control Unit }\end{array}$ & $\begin{array}{c}\text { of } \\
\text { Total } \%\end{array}$ \\
\hline Shanghai & 17 & - & - & - & - & 7 & 41.2 & 5 & 29.4 & 1 & 5.9 & 4 & 23.5 \\
\hline Guizhou & 34 & 2 & 5.9 & 18 & 52.9 & 5 & 14.7 & 2 & 5.9 & 2 & 5.9 & 5 & 14.7 \\
\hline Yunnan & 26 & 2 & 7.7 & 10 & 38.5 & 4 & 15.4 & 5 & 19.2 & 2 & 7.7 & 3 & 11.5 \\
\hline Hubei & 100 & - & - & 32 & 32.0 & 47 & 47.0 & 11 & 11.0 & 1 & 1.0 & 9 & 9.0 \\
\hline Sichuan & 80 & 4 & 5.0 & 31 & 38.8 & 26 & 32.5 & 9 & 11.3 & 3 & 3.8 & 7 & 8.8 \\
\hline Anhui & 50 & - & - & 17 & 34.0 & 19 & 38.0 & 6 & 12.0 & 4 & 8.0 & 4 & 8.0 \\
\hline Zhejiang & 20 & - & - & 6 & 30.0 & 5 & 25.0 & 7 & 35.0 & 1 & 5.0 & 1 & 5.0 \\
\hline Jiangsu & 42 & - & - & 5 & 11.9 & 19 & 45.2 & 13 & 31.0 & 4 & 9.5 & 1 & 2.4 \\
\hline Chongqing & 42 & - & - & 10 & 23.8 & 24 & 57.1 & 4 & 9.5 & 4 & 9.5 & - & - \\
\hline Hunan & 57 & 2 & 3.5 & 28 & 49.1 & 15 & 26.3 & 10 & 17.5 & 2 & 3.5 & - & - \\
\hline Jiangxi & 72 & - & - & 20 & 27.8 & 36 & 50.0 & 16 & 22.2 & - & - & - & - \\
\hline Henan & 9 & - & - & 3 & 33.3 & 5 & 55.6 & 1 & 11.1 & - & - & - & - \\
\hline Shaanxi & 15 & - & - & 13 & 86.7 & 2 & 13.3 & - & - & - & - & - & - \\
\hline Gansu & 3 & - & - & 3 & 100 & - & - & - & - & - & - & - & - \\
\hline Qinghai & 1 & 1 & 100.0 & - & - & - & - & - & - & - & - & - & - \\
\hline Total & 568 & 11 & 1.9 & 196 & 34.5 & 214 & 37.7 & 89 & 15.7 & 24 & 4.2 & 34 & 6.0 \\
\hline
\end{tabular}

Note: - Indicates no such item; of total\% means the percent of control unit with some water quality in the total number of control units in an administration district. 


\subsubsection{Relationship between Water Quality Status and Land Use}

Land use types are related to water pollution [31,32]. Land use change caused by human activities is one of the main causes of water quality changes in the river basin. Therefore, exploring the impact of land use types on river basin water quality has important theoretical and practical significance for rational conservation plan and management [32-34]. According to the land classification standard of the Second National Land Survey, land use is mainly classified into eight types: arable land, woodland, village land, landscape garden, grassland, rural community, city, and mining land. Based on the data of land survey and GIS spatial analysis tools, the above land use data were compared with a distribution map of control unit with water quality of Grade IV, Grade V and below Grade V in the Yangtze River to obtain the relationship of water quality to the land use type in the Yangtze River Basin.

The results of the statistical analysis are shown in Table 3. In general, in the control units with water quality below Grade III, water pollution was mainly from cultivated land, woodland and village land, accounting for 36.7\%, 35.96\% and 5.91\%, respectively, and 78.57\%, in total, while that of rural community, city, and mining land account for only 3.99\% in total. In addition, water pollution in control units with water quality of grades IV, V and Bad V is also mainly from cultivated land, woodland and village land. It is clear that agricultural land, which is mainly composed of cultivated land, woodland and village land, is an important water pollution source and agriculture has become the largest non-point source pollution industry in the Yangtze River Basin, far exceeding the urban and industrial pollution from rural community, city, and mining land. Therefore, water pollution prevention and control in the Yangtze River Basin should focus on agricultural pollution, while avoiding transferring urban and industrial pollution to agricultural and rural areas.

Table 3. Relationship between water quality and land use type in the Yangtze River Basin.

\begin{tabular}{ccccccccc}
\hline \multirow{2}{*}{$\begin{array}{c}\text { Water } \\
\text { Quality }\end{array}$} & \multicolumn{7}{c}{ Land use types } \\
\cline { 2 - 9 } & $\begin{array}{c}\text { Cultivated } \\
\text { Land\% }\end{array}$ & Woodland\% & Village\% & $\begin{array}{c}\text { Landscape } \\
\text { Garden\% }\end{array}$ & Grassland\% & $\begin{array}{c}\text { Rural } \\
\text { Community\% }\end{array}$ & City\% & $\begin{array}{c}\text { Mining } \\
\text { Land\% }\end{array}$ \\
\hline IV & 34.49 & 38.00 & 5.97 & 3.14 & 2.53 & 1.57 & 1.51 & 0.41 \\
V & 38.83 & 35.53 & 4.80 & 2.68 & 3.41 & 1.70 & 0.93 & 0.30 \\
Bad V & 42.02 & 29.55 & 6.82 & 2.50 & 2.36 & 2.80 & 3.46 & 0.45 \\
Average & 36.70 & 35.96 & 5.91 & 2.93 & 2.66 & 1.82 & 1.77 & 0.40 \\
\hline
\end{tabular}

\section{Discussion and Conclusions}

The idea of introducing control unit into river basin water environment management has been proven to be effective and recognized by the relevant departments of national, provincial, county and district level environmental management departments. The current control unit zoning methods depending mostly on the geographical and hydrological conditions are weak in practical application as they overlook the social and economic variations among the different administrative areas. Furthermore, the effective management of river water quality needs a bottom-up mechanism from the basic local government so the control unit zoning method should consider the administrative boundary and nature watershed division. Currently, the imperfect zoning method of control units has become the bottleneck of current refining and differential pollution control in China. Aiming at the objective of water environment protection in the key river basins in China during the "13th Five-Year Plan" period, this paper proposes a control unit zoning method that can effectively connect the natural features and three-level water resources classification, combine the township-level administrative division with watershed management, and comprehensively consider the distribution of pollution sources, socio-economics, land use and other factors in river basins. Based on this method, the Yangtze River Basin is divided into 568 control units. The provinces in the upper and middle reaches of the Yangtze River have better water quality, while those in the downstream reaches have relatively serious water pollution, especially those in the Yangtze River Delta area including Shanghai, Zhejiang and 
Jiangsu provinces, which have more severe water pollution problem and higher water environment management pressure. We further compared the land use and water quality within the control units in the Yangtze River and found that the water pollution mainly comes from agricultural pollution and agricultural pollution should be the focus for controlling water pollution in the Yangtze River Basin.

Based on our study, the Ministry of Environmental Protection of China on 20 June 2016 released the list of control units that need to improve water quality during the "13th Five-Year Plan" period, among which, 108 control units are located in the Yangtze River Basin, requiring the control unit related local governments to develop water quality standard programs with the control unit as the basic unit, implement the pollution control task one by one to the sewage units within the catchment units, clarify the control measures and compliance time limit, increase water pollution control efforts and ensure water quality to meet the target requirements. Our zoning method will help the Ministry of Environmental Protection of China to establish a bottom-up government system to control water pollution in the Yangtze River Basin with connecting each control unit to a corresponding local government. On the other hand, we believe the control unit zoning is a long-term, continuous, coordinated, feedback and perfecting process. During the process, cross-section location, sewage data, land use and socio-economic changes will occur, and their interactions are very complex. Therefore, one-time zoning is impossible to perfect. It can only be continuously evaluated and adjusted based on the changing situation towards a self-improved watershed water environmental management system. Our study will contribute to develop effective pollution control measures and implement specific responsibilities according to the pollution situation and the demands of the control unit of river basin water environment management.

Acknowledgments: The authors thank the National Key Research \& Development Program of China (2016YFC0502702) and the Natural Science Foundation of Fujian Province (2015J01168).

Author Contributions: F.D. and T.L. conceived and designed the experiments, performed the experiments; F.D. and Y.Y. analyzed the data; Z.Y. contributed analysis tools; F.D. and T.L. wrote the paper.

Conflicts of Interest: The authors declare no conflict of interest. The founding sponsors had no role in the design of the study; in the collection, analyses, or interpretation of data; in the writing of the manuscript, and in the decision to publish the results.

\section{References}

1. Raymond, P.A.; Oh, N.; Turner, R.E.; Broussard, W. Anthropogenically enhanced fluxes of water and carbon from the Mississippi River. Nature 2008, 451, 449-452. [CrossRef] [PubMed]

2. Tu, M.; Wang, F.; Zhou, Y.; Wang, S. Gridded water resource distribution simulation for China based on third-order basin data from 2002. Available online: http://www.mdpi.com/2071-1050/8/12/1309/htm (accessed on 28 July 2017).

3. Wang, X.; Pang, Y.; Wang, H.; Shen, C.; Wang, X. Emission control in river network system of the Taihu Basin for water quality assurance of water environmentally sensitive areas. Sustainability 2017, 9, 301. [CrossRef]

4. Zhang, L.; Gao, S.; Wei, B.; Li, Y.; Li, H.; Wang, L.; Ye, B. Effects of urbanization on rural drinking water quality in Beijing, China. Sustainability 2017, 9, 461. [CrossRef]

5. Wang, J.; Han, J.; Wang, L. Control unit zoning based on water eco-functional regionalization for the Liaohe river basin in Liaoning province. J. Meteorol. Environ. 2013, 29, 107-111. (In Chinese)

6. Patil, A.; Deng, Z.Q. Bayesian approach to estimating margin of safety for total maximum daily load development. J. Environ. Manag. 2011, 92, 910-918. [CrossRef] [PubMed]

7. Xie, Y.; Wang, D.; Zhao, K. Recognizing the key of water pollution control of Songhua River Basin by control uni. Environ. Prot. Sci. 2012, 38, 18-21. (In Chinese)

8. Xu, M.; Xie, Y.; Wang, D. Regionalization methods and practice for water pollution prevention and control in key river basin during twelfth five-year plan. Environ. Sci. Manag. 2013, 38, 74-77. (In Chinese)

9. Wang, D.; Wang, Y.; Xie, Y. Methodology and its application of control-unit division served for watershed environment management. J. Basic Sci. Eng. 2012, 20, 924-926. (In Chinese)

10. Santhi, C.; Arnold, J.G.; Williams, J.R. Application of a watershed model to evaluate management effects on point and nonpoint source pollution. Trans. ASAE 2001, 44, 1559-1570. [CrossRef] 
11. Yuan, Y.; Bingner, R.L.; Boydstun, J. Development of TMDL watershed implementation plan using Annualized AGNPS. Land Use Water Res. Res. 2006, 6, 21-28.

12. Grabrecht, J.; Martz, L.W. Network and sub-watershed parameters extracted from digital elevation models: The bills creek experience. JAWRA J. Am. Water Res. Assoc. 1993, 29, 909-916. [CrossRef]

13. Kangg, M.S.; Park, S.W.; Lee, J.J. Applying SWAT for TMDL programs to a small watershed containing rice paddy fields. Agric. Water Manag. 2006, 79, 72-92. [CrossRef]

14. Jha, M.; Wolter, C.F.; Schilling, K.E. Assessment of total maximum daily load implementation strategies for nitrate impairment of the Raccoon River, Iowa. J. Environ. Qual. 2010, 39, 1317-1327. [CrossRef]

15. Kroll, C.; Luz, J.; Allen, B. Developing a watershed characteristics database to improve low stream flow prediction. J. Hydrol. Eng. 2004, 9, 116-125. [CrossRef]

16. Bartram, J. Water Safety Plan Manual: Step-By-Step Risk Management for Drinking-Water Suppliers; World Health Organization: Genève, Switzerland, 2009.

17. Jin, T. Research on Dividing Control Unit of Water Pollution Prevention and Control for River Basin; Harbin Institute of Technology: Harbin, China, 2011. (In Chinese)

18. Lei, K.; Meng, W.; Qiao, F. Study and application of the technology on water quality target management for control unit. Eng. Sci. 2013, 15, 62-69. (In Chinese)

19. Moss, T.; Newig, J. Multilevel water governance and problems of scale: Setting the stage for a broader debate. Environ. Manag. 2010, 46, 1-6. [CrossRef] [PubMed]

20. Hering, D.; Borja, A.; Carstensen, J. The European water framework directive at the age of 10: A critical review of the achievements with recommendations for the future. Sci. Total Environ. 2010, 408, 4007-4019. [CrossRef] [PubMed]

21. Peng, K.; Wang, T.; Zhang, M. Division of control units in water environmental management in Yuanhe River Basin. J. Anhui Agric. Sci. 2012, 40, 924-926. (In Chinese)

22. Bao, K.; Peng, Y.; Sun, H. Up-to-standard assessment of water quality based on control unit division technology: A case study of Baidu Port. J. Hohai Univ. 2011, 39, 651-655. (In Chinese)

23. Xie, R.; Peng, Y.; Wang, X. Delineation of the water environmental comprehensive management area and control unit in the Trans-River cross-section of Taihu Basin. J. Fujian Norm. Univ. 2015, 31, 103-109. (In Chinese)

24. Wang, J.; Wu, W.; Jiang, H. Methodology and application for water pollution control zoning for watersheds of China. Adv. Water Sci. 2013, 24, 1-8. (In Chinese)

25. Xie, Y.; Xu, W.; Zhao, Y. Implementation of grid management of the environment. Environ. Prot. Sci. 2015, 41, 34-37. (In Chinese)

26. Zhao, J.; Liu, X.; Dong, R.; Shao, G. Landsenses ecology and ecological planning toward sustainable development. Int. J. Sustain. Dev. World Ecol. 2015. [CrossRef]

27. Borah, D.K.; Bera, M. Watershed-scale hydrologic and nonpoint-source pollution models: Review of applications. Trans. ASAE 2004, 47, 789-803. [CrossRef]

28. Chambliss, E. Modeling Land Use Patterns and Water Quality: An Evaluation of the pySPARROW Model; Duke University: Durham, NC, USA, 2008.

29. Raymong, H.A.; Bondoc, M.; Mcginnis, J. Using analytic element models to delineate drinking water source protection areas. Ground Water 2006, 44, 16-23. [CrossRef] [PubMed]

30. Zeilhofer, P.; Schwenk, L.M.; ONGA, N. A GIS-approach for determining permanent riparian protection areas in Mato Grosso, central Brazil. Appl. Geogr. 2011, 31, 990-997. [CrossRef]

31. Mehaffey, M.H.; Nash, M.S.; Wade, T.G. Linking land cover and water quality in New York city's water supply watersheds. Environ. Monit. Assess. 2005, 107, 29-44. [CrossRef] [PubMed]

32. Moreno, J.L.; Navarro, C.; de las Heras, J. Abiotic ecotypes in south-central Spanish rivers: Reference conditions and pollution. Environ. Pollut. 2006, 143, 388-396. [CrossRef] [PubMed] 
33. Yang, S.; Tang, C.; Liu, L. Relationships between river water quality and land use type at watershed scale. Chin. J. Appl. Ecol. 2013, 24, 1953-1961. (In Chinese)

34. Lin, Y.; Lin, W.; Li, H.; Wang, Y.; Hsu, C.; Lien, W.; Anthony, J.; Petway, J.R. Integrating social values and ecosystem services in systematic conservation planning: A case study in Datuan watershed. Sustainability 2017, 9, 718. [CrossRef] 